\title{
Youth Public Organizations in European Integration Processes of
}

\section{Ukraine}

\author{
Olena Aleksandrova, Oksana Salata \\ Borys Grinchenko Kyiv University, Kyiv, Ukraine
}

\begin{abstract}
It is described in the article the participation of Ukrainian youth NGOs in the process of European integration; the stages of the formation and development of youth NGOs, that revealed the pattern in their creation connected with the appropriate transformation of the values of modern Ukrainian youth. Pointed out that the formation of value orientations of Ukrainian youth took place with the development and consolidation of democratic values in Ukrainian society. Underlined the issue of solving problems of the formation and implementation of the state youth policy in Ukraine, participation of young people and youth associations in the processes of state building and development of a democratic society. It is proved that youth is an important factor in social and political processes in Ukraine and the most active participant in the state social and political life. The character of modern youth movements and the influence on informal youth initiatives on society are revealed. Some specific features of the development of modern youth public organizations in Ukraine and their involving in the process of decentralization-participation of young people in the activities of local government bodies, at all levels are outlined. The role of international organizations in supporting the youth organizations of Ukraine and involving the younger generation in international projects is shown, which also promoted the more active integration of Ukrainian society into the European community.
\end{abstract}

Keywords: Youth NGOs, civil society, European integration, political initiative

\section{Introduction}

Integration of Ukrainian youth into global and European community is an important issue of state policy. Youth in modern Ukraine is a generating force that seeks radical changes in all spheres of life: economic, social, political, spiritual-especially in the fields of science and education. This is precisely why the society and state have to ensure a leading and innovative participation of young people in state building processes, create conditions for meeting their spiritual and cultural needs, and afford equal opportunities for unveiling a professional, creative, and intellectual potential of the younger generation. The urgent need of today is gaining social experience by youth, achieving their competitiveness in the labor market and developing an ability of young people to live in civil society. The development stability of the Ukrainian state can be achieved through support to young families, high-quality education of the younger generation, formation of universal value orientations of young people, and instilling civic consciousness in youth.

Olena Aleksandrova, Doctor of Philosophical Sciences, professor, Dean of the Faculty of History and Philosophy, Borys Grinchenko Kyiv University, Kyiv, Ukraine.

Oksana Salata, Doctor of Historical Sciences, professor, Borys Grinchenko Kyiv University, Kyiv, Ukraine. 


\section{Literature Review}

The issue of youth public organizations and youth policy has been examined by numerous Ukrainian researchers, specifically by Polovynecz (2010), Kulik (1990; 2000), Golovonko (1997), Verbecz (1999), Karetna (2012), Kornievskyi and Yakushyk (1997), and Orlenko (2016). In their works, the above researchers address the issues of formation and implementation of the state youth policy in Ukraine and participation of young people and youth associations in the processes of state building and development of democratic society. Thus, Polovynets (2010) considered youth a social factor in the formation of civil society in Ukraine and the most active participant in public and political life. Kulik (2000) explored the nature of present-day youth movements and an impact of informal youth initiatives on society. The experience of the youth movement of the Ukrainian Diaspora is analyzed in the work by Golovonko (1997). In his scientific articles, Verbets (1999) covered the development of national consciousness of young people and realization of the youth potential in state building processes. Karetna's (2012) works showed the role of youth in the transformation processes of the social and economic spheres. Various aspects of the issue under review are dealt with in the work by Kornievskyi and Yakushyk (1997) "Youth Movement and Political Associations in Modern Ukraine". Orlenko's (2016) thesis research "Institutionalization of Youth Public Organizations in the Modern Political Process of Ukraine” also deserves attention.

In general, according to most researchers, the current European integration course of Ukraine is possible subject to an active involvement of youth in these processes. Under today's adverse conditions, it is the state which actively encourages the integration of young people into global and European community.

\section{Legislative Support of Participation of Youth Organizations in European Integration Processes}

The major directions of involving Ukrainian youth in European integration processes are outlined, in the first place, in Law of Ukraine “On National Youth Support Program for 2004-2008” as of 18.11.2003, where European integration of the younger generation became one of the main clauses, namely:

- initiating the development of draft international agreements in the field of youth policy and securing their implementation;

- regulation of the state policy in the field of external labor migration with the countries where young people of Ukraine come to for temporary work;

- expansion of opportunities for professional development and training of talented youth abroad through financial support of special international programs;

- promotion of international youth exchange among twinned cities, educational institutions, youth public organizations and their unions;

- expansion of international youth tourism in Ukraine;

- organization and holding of international art exhibitions, music, folklore and theater festivals, competitions and concerts as well as international scientific, information, and methodological and other events for young people;

- development and implementation at the state level of a program for learning foreign languages by citizens of Ukraine;

- promotion of the entry of national youth and children's public organizations and their unions into world and European youth entities;

- support to international programs of youth and children's public organizations and their unions; 
- assistance in setting up European youth centers;

- promotion of international youth cooperation in border areas;

- support to youth and children's public organization programs of for cooperation of young people of Ukraine with the Ukrainian Diaspora.

The development of Ukrainian society largely depends on how effectively young people exercise their rights to protect their interests. Ukraine has experienced a short (only 27 years) period of social and political life in which young people and youth organizations took quite an active part. Legislation aimed at regulating the activities of youth organizations consolidates virtually all democratic principles and mechanisms for their statutory activities. The specifics of the youth organization operation, especially in the recent decades, is primarily associated with the processes of formation of civil society and Euro-Atlantic integration of Ukraine as well as the expansion of foreign grant programs and youth initiatives in the territory of the Ukrainian state.

In 2014, the political system of Ukraine entered a new phase of its development when democratic institutions have been gradually consolidating their positions in society. The vision of the role of the state in regulating the activities of public organizations and encouraging youth activity aimed at maintaining the integrity of the country has been also changing. A good example of the above is Resolution No. 148 "On Approval of State Target Program 'Youth of Ukraine' for 2016-2020” of the Cabinet of Ministers of Ukraine, dated February 18, 2016.

The purpose of the program is to create favorable conditions for development and self-realization of Ukrainian youth and formation of its civic stand.

The approximate amount of funding for the program is UAH 501,284.68 thousand, including UAH 210,142.1 thousand from the state budget, UAH 277,882.58 thousand owing to local budgets, and UAH 13,260 thousand from other sources.

Objectives of the Program are as follows:

1. Formation of civic stand and national-patriotic education of youth.

2. Popularization and promotion of a healthy and safe lifestyle as well as health culture among young people.

3. Acquisition by young people of knowledge, skills, and other competencies outside the education system (development of non-formal education).

4. Creation of an environment for youth employment (primary and secondary employment as well as self-employment of young people).

5. Creating conditions for provision of housing to young people.

6. Partner support to young people living in the temporarily occupied territory of Ukraine and internally displaced persons.

7. Financial support to youth and children's public organizations.

8. Promotion of international youth cooperation.

\section{Stages of Formation and Development of Youth Public Organizations}

There is generally a pattern in the setting up of youth public organizations, which is associated with a corresponding transformation of modern Ukrainian youth values. The formation of value orientations of Ukrainian youth was of saltatory nature and varied from order to chaos, i.e., from a long chaotic to short ordered state of Ukrainian society: 


\section{From the "Revolution on Granite" to the "Orange Revolution"}

Stage I-from minimization of social changes and the absence of large-scale conflicts in violent forms (1991-1994 — order) through the formation of a double institutional system in the economy (1994-2003—chaos) to the "Orange Revolution" (the late 2004-2005 — order) that was underpinned by a contradiction between the existing institutional system and needs of active segments of the population, including opposition political elites which had failed to find their place in power. The basis for a coordinated liaison of those active segments of the population was the realization that society had seen no changes which could be qualified as progress or achievements while ideological principles of the short-term consensus were European democratic values.

It should be noted that the ordered actions in the first years of Ukrainian independence were preceded by "chaos" in value orientations of Ukrainian sodium and contradictions in identifying future vectors of its development. In the late 1980s-early to 1990s, it was the student movement that markedly manifested itself in the political struggle which resulted in the proclamation of the Act of State Independence of Ukraine in 1991. Below is given a short retrospective of those events.

The student movement was most developed in the western regions of Ukraine. Its first manifestation was the creation of "Student Brotherhood" in May 1989 on the initiative of students of the Lviv University. In December 1989, a new student organization—-the Ukrainian Student Union (USU)—was set up at the founding congress in Kyiv.

One of the first actions of the Ukrainian Student Union and "Student Brotherhood" was the organization of a youth strike in February 1990 in response to the arrest of Kyiv students (Melnykov, 2005), which was later called the "Revolution on Granite". The political environment in the Republic at the time became particularly acute due to drafting a treaty of the union. Recognizing the seriousness of the situation in the republic and the inability of the parliament to resolve that issue in the interests of the sovereign state, members of the Ukrainian Student Union and "Student Brotherhood" began an unprecedented action in the political history of Ukraine on October 2, 1990 - a protest that took the shape of a political hunger strike in the October Revolution Square (nowadays - the Independence Square (Maidan)) in Kyiv. Among the protesters' demands to the Verkhovna Rada of the Republic were: calling new elections to the Verkhovna Rada on a multi-party basis; dropping the demands of the center as to signing the treaty of the Union, etc. (Kulik, 1990).

The political protest action of students through the hunger strike became an important event in the struggle for democratic transformations and striving of young people for decisive radical changes in society. In his book Generation of the "Velvet Revolution", Oles Doniy, an activist of the Revolution on Granite, a fifth-year student of the History Faculty of the Kyiv University and the Chairman of the Ukrainian Student Union at the time, writes:

The student hunger strike became a symbol of the birth of new society. It was October 1990, when young people acted as a completely independent political force and succeeded, which became the starting point rather than August 1991, completely divorced from reality, or hectic December 1991. It was in October of 1990 when it was recognized that "the generation of 1990” acted as a separate historical and social group. (Donij, 1999, p. 24)

Having worked up some prerequisites for adoption of an Act of Declaration of Independence of Ukraine on August 24, 1991, the student protest movement exhausted itself for 10 years. In broad terms, one may say that youth public organizations in Ukraine were springing up over the period from the late 1980s to mid-1990s. 
The late 1990s-early to 2000s saw the development of youth entities in Ukraine, which covered both the level of regional youth parliaments, youth administrations of regions, districts and the level of cities, towns, youth councils, and youth municipalities. An example of activity of such youth entity at the level of a city is the Mykolaiv youth municipality set up in October 2000 as a union of youth organizations, which comprised representatives of 23 youth organizations, student labor unions, and student self-government bodies.

Specifically, the youth municipality objectives comprised the following: ensuring young citizens' influence on decision-making by all state authorities and local self-government; drawing attention to the importance of active youth participation in the political life of Ukraine; assistance in implementation of the youth policy in Mykolaiv; and lobbying and protection of the rights of youth in adopting regulatory documents by state authorities and local self-government.

Authority and respect in various fields of youth activity over that period were gained by such new national youth public organizations and associations of student self-government bodies as "All-Ukrainian Student Council”, "Student Council of Kyiv”, "Foundation of Regional Initiatives”, "Student Republic”, "Youth Education”, "Debate Academy”, "Youth Nationalist Congress”, "Board of Young Managers and Lawyers”, "European Youth of Ukraine”, "Union of Initiative Youth”, and some other (Kulik, 2000).

At the end of 2000 and during 2001, Ukrainian students demonstrated their active protest potential again. It was at that time that a campaign of protests of opposition forces began, which went down in the history of Ukraine under the name "Ukraine without Kuchma". The opposition clearly outlined the purpose of the organization of mass protests of citizens, focusing on two fundamental things: firstly, changes in the system of power, which was characterized as authoritarian; secondly, an early resignation of President L. Kuchma. The action "Ukraine without Kuchma" was supported by 24 political parties (both nationalist and some left-wing parties) and public organizations, including the Ukrainian Communist Youth Union, the Ukrainian Student Union and "Student Brotherhood". An appeal to Ukrainian youth from the senior companions who had taken part yet in the hunger strike in 1990 was spread through student and other network channels of communication as well as media. In particular, it accused the regime of a scanty size of student scholarships, corruption in the educational system, conditions which forced graduates to travel abroad etc. In the end, young people were called for supporting the elimination of L. Kuchma's regime (2016).

The authors of this article agree that the protests of 2001 were a certain rehearsal, a try-on of forces of the students who had taken no active part in the social and political life of the country by that time since the "Revolution on Granite". However, a few months before the presidential elections of 2004, when there had been no united orange movement, there had come into sight a civil campaign called "Pora", which tried to stir up society with its original actions. Some political analysts compared the Ukrainian "Pora" with the Serbian “Otpor”, Georgian “Kmara”, Albanian "Myaft”, and Belarussian "Zubr” and predicted the Serbian or Georgian scenarios for Ukraine (Guzo, 2005). Young people from the Ukrainian "Pora”, most of whom were students of Ukrainian universities, organized outdoor actions, campaigning for no presidential candidate but urging people to be vigilant and authorities honest (Palagnyuk, 2013).

Thus, during 2004, the apathy of youth organizations to politics passed, which marked a new "activist period" for the younger generation. The political involvement of young people during the presidential campaign of 2004 manifested itself in the electoral activity as well as protest behavior. It was during that period that many youth organizations were registered, such as the above "Pora" and "Youth Ukraine", most of them supporting European democratic values. In addition, territorial consolidation of youth from various regions of 
Ukraine was in progress at the time. Representatives of the youth who stood at the Maidan or vice versa were its ardent opponents turned into leaders of youth public organizations to continue upholding their interests.

\section{After the "Orange Revolution" and Before the "Revolution of Dignity"}

Stage II (2006-2013 - chaos) began with the return to the pre-revolutionary level in the course of democratization, which again resulted in manifestation of the ambivalence of mass consciousness in all spheres of human life. That trend gained noticeable strength due to the final convergence of the financial and economic oligarchy with bureaucracy and achieved momentum in the context of the global financial and economic crisis.

During that period, there was close cooperation between political parties and youth organizations progressively observed in political space of Ukraine. Specifically, the well-tried mechanism of setting up party youth structures which statutory documents were guided by ideological foundations of political parties was actively used. Such organizations as "Ukrainian Social Democratic Youth", "People’s Democratic Youth League”, “Molodoy Rukh”, “Young Democrats”, “Union of Agrarian Youth”, “Youth of Regions of Ukraine”, "Batkivshchyna Molodaya", and many other were clearly set to achieve their goals together with those political parties that were their strategic partners (Kerbal, 2008). That trend in activities of youth organizations resulted in the fact that young people taking their political lead from a party with its already backward ideas and activities were unable to make a breakthrough and offer real changes.

Another characteristic of that period is a wider involvement of youth in local decision-making. The most influential youth organizations at the local level include the following: "Youth Center 'Initiative' (the city of Kharkiv), Youth Public Organization (hereinafter YPO) "Ukrainian Youth League" (the city of Bila Tserkva), YPO "Youth Executive Committee” (the city of Kerch), "Youth Discussion Center” (the city of Donetsk), YPO "Leadership" (the city of Zhytomyr), YPO "Youth Union" (the city of Kyiv), YPO "Unity" (the city of Ternopil), YPO "Regional Initiatives Fund” (the city of Sumy), the Youth Initiative Center "Totem” (the city of Kherson), the YPO "Youth Perspectives Center" (the city of Khmelnytskyi), and other (Guczalova, 2012).

Assessing the activities of those organizations, it would be fair to point out that to begin with, they tried to involve young people in active actions, and carry out educational work for local community awareness of their rights. Such priorities as promoting positive changes in society and solving urgent problems of civil society development in a particular area still remain relevant at the present development stage of Ukrainian society.

International organizations supporting youth organizations and involving the younger generation in international projects that will contribute to a more active integration of Ukrainian society into European community have also begun to effectively operate in Ukraine. Among such organizations the most active are the Association "European Youth Parliament-Ukraine" (the city of Kyiv), "Association of Students of Europe-Dnipro” (the city of Dnipro), "Talents of the Third Millennium” (the city of Kharkiv), etc.

Ukrainian researchers single out the following youth organizations over that period by the directions and types of their activities (Guczalova, 2012):

- consultancy (“Ukrainian Youth Information Agency”);

- assistance to other non-governmental organizations (National Youth Center "Environmental Initiatives”);

- influence on the legislative system (Ukrainian Union of Young Deputies, public organization "Guardians of Law”);

- civil society development (All-Ukrainian Youth Public Organization “Ukraine-XXI”);

- European integration (“Ukrainian Association of European Studies”). 


\section{From the "Revolution of Dignity" to the Present}

Stage III began with the "Revolution of Dignity" (the late 2013-the early 2014-a short-term conditional order which was manifested in the coordinated liaison of pro-European political forces) whose ideological benchmarks were again the values of European democracy. That stage has been lasting till today (the mid-2014-2018 — chaos) and features external aggression and destruction in the economy, which has not only caused a deep economic crisis but also exacerbated the binarity of value orientations of young people.

At the beginning of 2014, there were 5,450 youth organizations i.e. their number grew 9.3 times from 1995 to 2012: from 24 to 224 in 2012 and 24 times in 2013 alone (2014).

A continuous increase in the number of youth organizations over the recent five years marked the beginning of the modern period of their development in Ukraine. According to Fishchuk (2012), such activity indicates the desire of young people to participate in an organized youth movement and therefore claim state support for their initiatives. Saying that, Ukraine's achievements regarding the growing involvement of youth organizations in political processes should not be aggrandized. Youth public organizations as a form of manifestation of youth social activity have been experiencing together with the Ukrainian state a difficult period of economic and socio-political transformations. The organized youth movement in Ukraine continues to develop, institutionalize, and form a developed multi-level system from national to city and district organizations, improving liaison mechanisms both in the horizontal of communications and with the vertical of power. Today, in common with the initial stage of formation (the 1990s), organizations, by their existence, conflict with no provision of the national strategy for youth policy development of Ukraine but unfortunately often depend on it.

In addition to socio-political youth organizations that influence public opinion, there are also radical destructive youth public organizations in Ukraine, which prove themselves to be very "unstable” and sometimes sharp in their statements and actions. Crisis phenomena in the policy and social development of Ukraine contributed to the activation of their operation. It should be noted that the social basis of such organizations is marginal youth (Fishchuk, 2012).

Today, there is also such negative phenomenon observed as the setting up and operation of public organizations for the sake of securing foreign grants and their misuse. As a consequence, despite the existence of hundreds of youth public organizations in each Ukrainian city, the majority of local real-life problems have not yet been solved.

At the same time, contemporary Ukrainian politicians often underestimate and deliberately underrate the importance of proposals made by youth public organizations in respect of many socially significant problems, forgetting that in this way the state and its institutions can maximally contribute to meeting the needs and demands of the whole younger generation. In addition, representatives of the Ukrainian political elite are unwilling to distinguish between such associations which feature specificity and diversity, perceiving all youth organizations as political entities, although Ukrainian society may have as many youth organizations as group youth interests.

It should be mentioned that due to the fact that there is a very great number of youth public organizations, the authorities (both local and state) should have differentiated approaches and mechanisms of cooperation with each of the variety. Building on works of such scientists as Kulik (2000), Polovynets (2010), and Golovonko (1997), the authors of this research have improved the classification of youth organizations, proceeding from 
the present-day realities of Ukrainian society development (the data source of legally registered national youth public organizations is the Ministry of Ukraine for Family, Youth and Sports):

- youth political organizations (the Association of Interns of the Verkhovna Rada of Ukraine; Democratic Transformations of Ukraine; Liberal Youth Association; Young People’s Movement; National Democratic League of Youth; Organization of the Republican Christian Party "Republican Christian Youth"; Social Democratic Youth Alliance of Ukraine; Social-Democratic Youth of Ukraine; Socialist Youth Congress; Agrarian Youth Union; Ukrainian Social Democratic Youth; Christian Democratic Youth of Ukraine and other);

- youth professional associations (the Agrarian Youth Union, Association of Young Doctors of Ukraine; Association of Future Lawyers of Ukraine; Association of Young Entrepreneurs of Ukraine; Association of Youth Labor Unions of Ukraine; All-Ukrainian Association of Young Scientists; All-Ukrainian Council of Young Scientists and Specialists; All-Ukrainian Union of Young Entrepreneurs and Businessmen; National Youth Pedagogical Council of Ukraine; League of Parliamentary Assistants; Youth Academy of Sciences; Youth Marine League of Ukraine (the city of Sevastopol); Young Agrarians Union of Ukraine; Union of Young Civil Servants of Ukraine; Union of Creative Youth of Ukraine "Liga Artis"; Ukrainian Youth Information Agency; Ukrainian Union of Young Deputies; Ukrainian National Union of Young Lawyers);

- organizations by interests (the Association of Guides of Ukraine; Association "KVN of Ukraine"; Association of Young Deputies of Ukraine; Association of Youth Organizations of Ukraine "Spectrum"; All-Ukrainian Association of Youth Cooperation "Alternative-B"; All-Ukrainian Public Association "New Generation"; All-Ukrainian Youth Public Organization "International Cooperation Club "Mandry"; All-Ukrainian Union of Public Organizations "Scouts of Ukraine”; All-Ukrainian Youth Public Organization "Youth of the Third Millennium"; All-Ukrainian Youth Public Organization "Youth Initiatives Center School of Leaders"; All-Ukrainian Union of Youth Public Organizations USMO; All-Ukrainian Youth Public Organization "Youth Solidarity"; Moloda Prosvita (Youth Education); Youth Information Center "Euro-26-Zarevo"; PLAST-National Scout Organization of Ukraine; Council of Young Entrepreneurs of Ukraine; Ukrainian Youth Foundation of Political and Legal Research "MATEZIS”; Center for Support of Rural Youth; Ukrainian Children and Youth Association "SICH”);

- national-cultural and sports organizations (the All-Ukrainian Association of Young Folklore Researchers; Youth Nationalist Congress; All-Ukrainian Youth Organization "Siaivo"; All-Ukrainian Youth Art Center "Perlyny Sezonu”; Public Organization "Muza”; Ukraine-Festival; Modern Choreography and Vocal Federation "Premier League”; Snowboarding and Ski Tour Federation of Ukraine);

- student organizations (the All-Ukrainian Council of Students; All-Ukrainian Public Association "Student Brotherhood”; Association of Student Youth "Zarevo”; All-Ukrainian Association of Political Science Students, Ukrainian Student Union);

- subculture of modern youth (“hippie”, “emo”, “Goth”, “punk”, et al.) (Kulik, 2000);

- organizations which contribute to solution of social problems (the All-Ukrainian Youth Public Organization "Promotion Union of Youth Housing Crediting"; All-Ukrainian Youth Hostel Association; Public Organization "Institute of Drug Abuse and Drug-Related Crime Problems"; Youth for Tax Reforms; Youth against Corruption; New Initiatives of Youth; Association of Human Rights Organizers of Students of Ukraine, All-Ukrainian Youth Association "Youth for Welfare") ; 
- environmental organizations (Green Energy of the Future "Laboratory of Ideas", a student public organization set up in Ivan Franko National University of Lviv);

- volunteer organizations. This classification can be supplemented with volunteer organizations as their members and/or founders are mostly young people. They became most active after 2014. Today there are about 250 legally registered volunteer organizations in Ukraine, the most influential, according to the Ministry of Information Policy of Ukraine, being (2018): the Coordination Center of the city of Kyiv, SOS Army, All-Ukrainian Association "Patriot”, Army Charity Fund "Come Back Alive”, DemAlians "Help”, Volunteer Association "Everyone can Help", Charity Fund "Phoenix Wings”, "Support the Army of Ukraine, Come Back Alive, Volunteers without Borders.

The main lines of volunteer organizations' activities are: (1) social, psychological, information, and legal support to families of soldiers of the Antiterrorist Operation (ATO) in the east of Ukraine and soldiers who were injured as a result of hostilities, training in psychological self-help; (2) assistance to internally displaced persons, those who suffered in the ATO zone (the wounded and tortured), families of victims, humanitarian assistance in the ATO zone (food, clothing, household essentials, and medicines), assistance to social groups which are neglected due to military actions (dwellers of children's homes, boarding schools, shelters for the elderly, rehabilitation centers, etc.); (3) involvement of citizens and representatives of business community in organization of first-line material and technical support to the Armed Forces of Ukraine and law enforcement agencies fighting in the East of Ukraine-purchase of necessary military ammunition, means of protection, communication and intelligence, uniforms and food as well as their delivery directly to the front; and (4) assistance in resettlement and employment to people forced to move.

As to the characteristics of each of the above types, at the present stage youth organizations in Ukraine feature some general trends in developing objectives of their activities, which are recorded in their statutes. In most cases, they choose the following priority goals: development of civic initiatives; protection of rights and representation of interests of young people; socio-political as well as information and analytical activities; educational activities; involvement of active youth in decision-making by local authorities.

Local and regional organizations have great prospects in local political processes of Ukraine. Such prospects are building up despite the growth of state support to local self-government and delegation of a direct decision-making power to local communities.

The most typical mechanisms of youth organizations involvement in political processes are:

- establishment of mutually beneficial relations with authorities (local, regional and state);

- creation and effective operation of all possible forms of youth local self-government (youth municipalities);

- involvement of representatives of youth organizations as advisers-consultants in activities of authorities and special committees;

- pinpointing attention of authorities upon existing problems at the national or local levels;

- development and implementation of YPOs' own proposals aimed at solution of socially important issues;

- introduction of amendments in legislation in the form of proposed drafts of respective documents;

- carrying out statutory activities of organizations, quality control and reporting on implementation of state or local social programs;

- liaison of youth organizations with each other; 
- cooperation with organizations, societies, and youth entities for sharing positive experiences and establishing dialogue.

\section{Conclusion}

To sum up, it is necessary to outline some characteristic features of the development of modern youth public organizations in Ukraine. In the context of democratic value development in Ukrainian society, it is becoming possible to set up an ever growing number of youth organizations. These organizations are gradually acquiring the rights to influence the legislative system and the process of European integration in Ukraine. Thus, today it is important that youth organizations should be involved in the decentralization process-youth participation in local self-government at all levels. With the above in view, it is promising to examine the role of young people in the formation and operation of local governments in Ukraine.

\section{References}

Appeal of young participants of the action “Ukraine without Kuchma!” to Ukrainian youth. (2001). Maidan-Inform. Retrieved from http://maidanua.org/arch/petit/989948886.html [in Ukrainian]

Donij, O. (1999). Generation of velvet revolution. (How do we survive until 2009?) K: Smoloskyp [in Ukrainian].

Fishhuk, A. (2012). Problems of development of the modern youth movement. Retrieved from http://old.niss.gov.ua/Monitor/november08/18.htm [in Ukrainian]

Golovonko, V. A. (1997). Ukrainian Youth Movement in the 21st Century / Ukr Research Institute of Youth Problems. K.A.D. [in Ukrainian]

Guczalova, M. V. (2012). Contemporary youth organizations in Ukraine: Trends, problems and mechanisms of participation in political processes // Scientific works of the Pavel Mohyly Black Sea State University. Sir: Political Science, Vol. 182, Vip. 170, 111-115. Retrieved from: http://nbuv.gov.ua/UJRN/Npchdupol_2012_182_170_25 [in Ukrainian]

Guzo, G. (2005). Revolutionary student // High Castle. May 4th. [in Ukrainian]

Karetna, O. O. (2012). National University “Odessa Law Academy”: The role of youth in the process of socio-economic transformation of Ukraine. Retrieved from http://dspace.onua.edu.ua/bitstream/handle/11300/1196/Karetna.pdf?sequence=1\&isAllowed=y [in Ukrainian]

Kerbal, M. O. (2008). The role and place of youth associations in political life. Retrieved from http://www.nbuv.gov.ua/portal/Soc_Gum/Npchdu/Politology/2008_66/66-18.pdf [in Ukrainian]

Korniyevskyj, O. A., \& Yakushyk, V. M. (1997). Youth movement and political associations in modern Ukraine. Kyiv: Genesis, 1997 [in Ukrainian]

Kulik, V. (1990). Student protest action in October 1990. Retrieved from http://golob.narod.ru/volchet.html [in Ukrainian]

Kulik, V. (2000). Young Ukraine: A contemporary organized youth movement and informal initiative: Research. K.: Center for Research on Civil Society Issues [in Ukrainian]

Law of Ukraine No. 1281-IV on the National Program for the Support of the Youth of Ukraine and Ukrainian Youth for 2004-2008. (2003). Retrieved from http://dsmsu.gov.ua/media/Transfered/documents/2003/11/18/3/2003_1281-IV_zu.pdf [in Ukrainian]

Melnykov, D. O. (2015). Youth movement in Ukraine: stages and problems of development (80th-90th years of the twentieth century. Retrieved from http://www.info-library.com.ua/books-text-11166.html [in Ukrainian]

Number of Registered Public Associations, Trade Unions, Political Parties and Charitable Organizations in 2013. (2014). Express Issue. State Statistics Service of Ukraine dated March 6, 2014. Retrieved from http://www.ukrstat.gov.ua/ [in Ukrainian]

Orlenko, M. V. (2016). Institutionalization of youth civic organizations in the modern political process in Ukraine [Text]: dissertation. Candidate flight. Sciences: 23.00.02 / Marina Vladimirovna Orlenko; Black Sea state Un-t them. P. Graves-Mykolayiv. [in Ukrainian]

Palagnyuk, V. O. (2013) Student place in protest campaigns in independent Ukraine: A retrospective approach. State and Law. Issue 60. [in Ukrainian]

Polovynecz, A. M. (2010) Youth NGOs: Classification criteria. Retrieved from http://www.nbuv.gov.ua/e journals/dutp/2010_2/txts/10pamokk.pdf [in Ukrainian] 
Resolution of the Cabinet of Ministers of Ukraine dated February 18, 2016, No. 148 on approval of the State Target Program "Youth of Ukraine" for 2016-2020 and amending certain resolutions of the Cabinet of Ministers of Ukraine. (2016). Retrieved from http://dsmsu.gov.ua/media/2016/03/12/7/povnii_tekst_ostatochno__1_.pdf [in Ukrainian]

Verbecz, V. (1999). Problems of forming the national consciousness of youth // Scientific notes “Ostroh Academy”. Darling. [in Ukrainian]

Volunteer Organizations. (2018). Retrieved from http://mip.gov.ua/content/volonterski--organizacii.html [in Ukrainian] 